\title{
Open cells exhibit weaker entrainment of free-tropospheric biomass burn- ing aerosol into the south-east Atlantic boundary layer
}

Steven J. Abel et al.

Correspondence to: Steven Abel (steven.abel@metoffice.gov.uk)

The copyright of individual parts of the supplement might differ from the CC BY 4.0 License. 


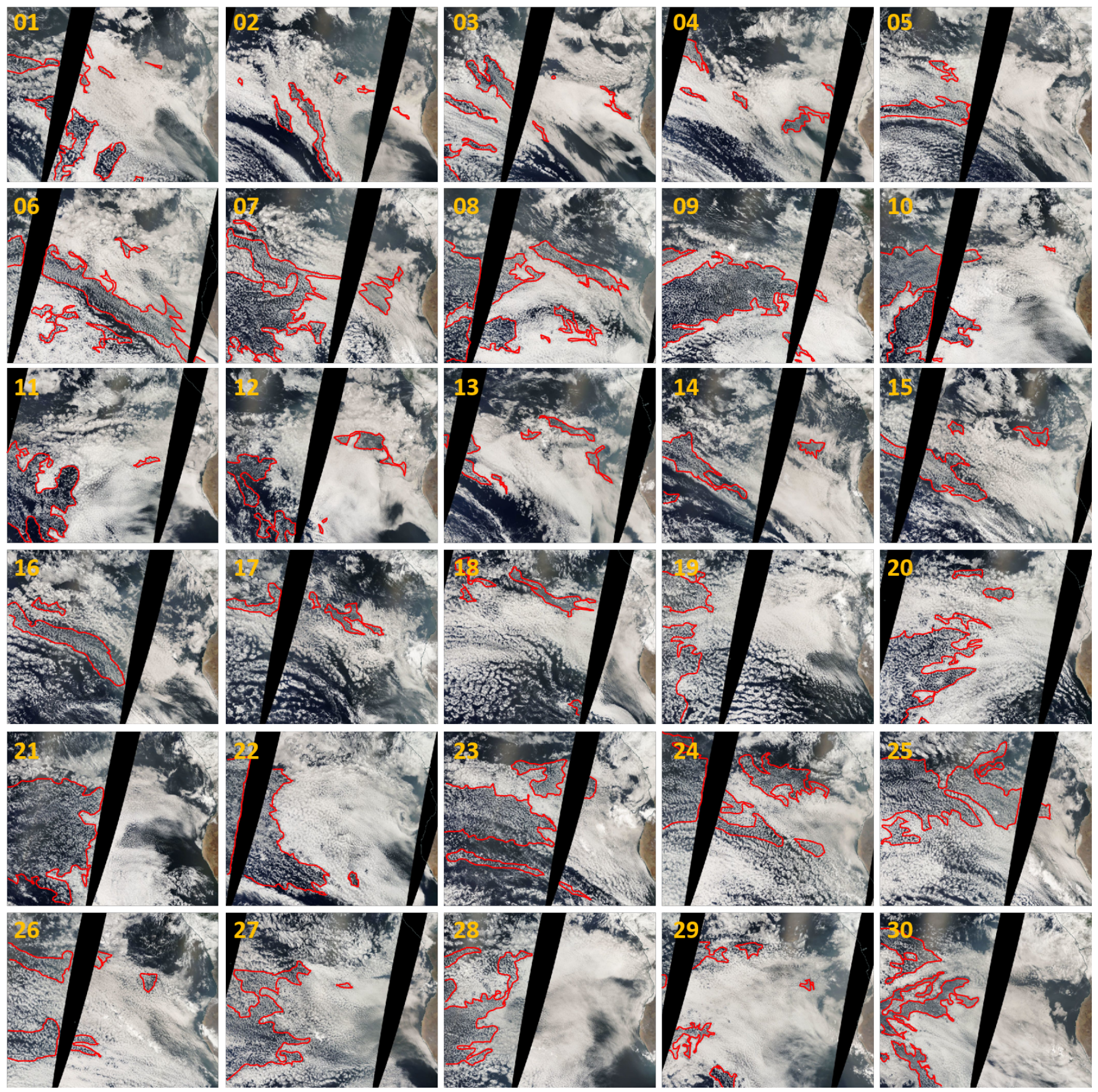

Figure S 1. Examples of the manual identification of open cell regions (outlined in red) from day-time MODIS Terra imagery, covering the period from the 1st to 30th September 2010. The MODIS imagery was obtained from NASA Worldview. 